\title{
ПЕРЕДУМОВИ РЕАЛІЗАЦЇ̈ КОНКУРЕНТНИХ ПЕРЕВАГ ВОДНОГО ТРАНСПОРТУ УКРАЇНИ
}

\author{
Одеський наиіональний університет імені I.I. Мечникова \\ Інститут проблем ринку та економіко-екологічних досліджень НАН України
}

\begin{abstract}
Розвиток вітчизняної системи водного транспорту та їі інфраструктури у сучасних умовах розвитку економіки України характеризуються посиленням інтеграційних процесів у світову економічну систему, що здатна забезпечити підвищення інвестиційної привабливості країни через нарощення транспортних потоків, конкурентоспроможності, скорочення термінів доставки вантажів тощо та матиме мультиплікативний ефект і на інші сфери економічної діяльності. Тому роботу направлено на визначення передумов реалізації конкурентних переваг водного транспорту України. На основі аналізу перевезень вантажів за видами транспорту встановлено кардинальний перерозподіл структури перевезень вантажів у сторону залізничних. Частина вантажних перевезень здійснюється водним транспортом України, враховуючи перевезення морським та річковим видами транспорту. На відміну від країн Європейського союзу, в Україні внутрішніми водними шляхами вантажі, зокрема будівельні, різна руда, хлібні види вантажів, різні метали тощо, транспортуються переважно каботажними перевезеннями. В низці країн Європейського союзу, зокрема у Нідерландах, Німеччині і Бельгії, спостерігається виразна взаємозалежність між обсягами перевезення вантажів та промисловістю, яка формує переважну вантажну базу. Внутрішні водні шляхи Свропи типізовані, на яких використовуються уніфіковані баржі, вантажопідйомність яких залежить від глибини. Масштабне використання потенціалу внутрішніх водних шляхів Свропи враховує високі показників екологічної стійкості та енергоефективності, підтримуючи безпеку клімату та навколишнього середовища. Морська транспортна система України представлена 13 морськими портами, проте рівень їхньої завантаженості знаходиться нижче 50\% значення у той час, коли відбувається розвиток трансконтинентальних морських маршрутів із великою кількістю інтеграційних точок на своєму шляху. Країнами Європи, що мають вихід к морю, зокрема Нідерланди, Італія, Іспанія, Об'єднане Королівство, забезпечується переважний вантажопотік. Тому для участі морських портів України у реалізації перевезень транс'європейськими та трансконтинентальними маршрутами першочерговим завданням виступає підвищення конкурентоспроможності через вирішення проблем не тільки заходу до портів великогабаритних суден, а й шляхом вирішення врегулювання нормативноправового, технологічно-інформаційного та економіко-екологічного забезпечення, зокрема за допомогою впровадження концепції «розумного порту», яка $\epsilon$ головним трендом в трансформації та цифровізації портів світу та передбачає об'єднання всіх учасників глобального ланцюга поставок у єдину взаємопов'язану мережу на основі цифрової платформи із тестуванням штучного інтелекту.

Ключові слова: передумови, розвиток, морський та річковий транспорт, конкурентні переваги, перевезення вантажів, пропускна спроможність, вантажопотік, рівень завантаженості, смарт порт, ичирровий транспортний коридор
\end{abstract}

\section{PREREQUISITES FOR REALIZING THE COMPETITIVE ADVANTAGES OF WATER TRANSPORT OF UKRAINE}

\author{
National University of Life and Environmental Sciences of Ukraine \\ Institute of Market Problems and Economic-Ecological Research of the NAS of Ukraine
}

The development of the domestic system of water transport and its infrastructure in the modern conditions of the development of the Ukrainian economy is characterized by the strengthening of integration processes into the world economic system, which is capable of increasing the investment attractiveness of the country through increasing transport flows, competitiveness, reducing the delivery time of goods, etc. and have a multiplier effect on other areas of economic activity. Therefore, the work is aimed at determining the prerequisites for the implementation of the competitive advantages of water transport in Ukraine. Based on the analysis of cargo transportation by mode of transport, a radical redistribution of the structure of cargo transportation towards rail has been established. Part of cargo transportation is carried out by water transport of Ukraine, taking into account 
transportation by sea and river transport. In contrast to the countries of the European Union, in Ukraine by inland waterways, cargo, in particular construction, various ores, grain types of cargo, various metals and others, are transported mainly by cabotage. In several countries of the European Union, in particular the Netherlands, Germany and Belgium, there is a clear interdependence between the volume of freight traffic and industry, which forms a large freight base. The inland waterways of Europe are standardized, using standardized barges, the carrying capacity of which depends on the depth. The large-scale use of the potential of Europe's inland waterways takes into account high indicators of environmental sustainability and energy efficiency, maintaining a safe climate and environment. The maritime transport system of Ukraine is represented by 13 seaports, but their level of congestion is below $50 \%$ of the value at a time when transcontinental sea routes are developing with a large number of integration points on their way. European countries with access to the sea, in particular the Netherlands, Italy, Spain, Great Britain, ensure the predominant cargo traffic. Therefore, for the participation of the seaports of Ukraine in the implementation of transportations by trans-European and transcontinental routes, the priority task is to increase competitiveness by solving the problems of not only entering the ports of large ships, but also regulating legal, technological, information and economic and environmental support, in particular through the introduction of the concept "Smart port", which is the main trend in the transformation and digitalization of the world's ports and involves the unification of all participants in the global supply chain into a single interconnected network based on a digital platform with artificial intelligence testing.

Key words: Key words: prerequisites, development, sea and river transport, competitive advantages, cargo transportation, throughput, freight traffic, congestion level, smart port, digital transport corridor.

Постановка завдання у загальному вигляді i ï̈ зв'язок 3 важливими науковими та практичними завданнями. У сучасних умовах розвитку економіки України, які характеризуються посиленням інтеграційних процесів у світову економічну систему, особливого значення набуває розвиток вітчизняної транспортної системи та іiі інфраструктури, зокрема водного транспорту. Це обумовлено не тільки тим, що перевезення водним транспортом є більш економними (дешевими), екологічними, енергоефективним у порівнянні з іншими видами транспорту, але й забезпечують підвищення інвестиційної привабливості країни через нарощення транспортних потоків, конкурентоспроможності вітчизняної продукції за рахунок більш низької собівартості, скорочення термінів доставки, збільшенням податкових та неподаткових надходжень до державного бюджету тощо. При цьому розвиток водного транспорту України матиме мультиплікативний ефект і на інші сфери економічної діяльності, зокрема сільське та лісове господарства, промисловість, торгівля тощо.

Зважаючи на те що, водна транспортна система світу є доволі неоднорідною структурою за інституціональною, економічної, техніко-технологічною та соціальною характеристикою, управління їі розвитком більшою мірою залежить від політики різних країн. Розвиток інфраструктури водного транспорту $\epsilon$ важливим не тільки на національному, але і на міжнародному рівні, оскільки вона виступає одним із елементів загальної транспортної системи, яка забезпечує зв'язок між різними галузями економіки, здійснюючи рух продукції зі сфери виробництва до сфери обігу та виступаючи ланкою, що продовжує процес виробництва в межах обігу.

Тому для підвищення конкурентоспроможності, формування сприятливого підприємницького клімату, забезпечення сучасних умов щодо сталого розвитку водного транспорту низкою стратегічних документів України передбачено нагальні завдання, що потребують вирішення, зокрема Указом Президента України «Про Цілі сталого розвитку України на період до 2030 року» [1], Розпорядженнями Кабінету Міністрів України «Про схвалення Національної транспортної стратегії України на період до 2030 року» [2] та «Про затвердження Стратегії розвитку морських портів України на період до 2038 року» [3], прийняття Закону України «Про внутрішній водний транспорт» [4], а також іншими важливими нормативно-правовими документами та стратегічними планами розвитку на середньо та короткостроковий період Міністерства інфраструктури України, Адміністрації морських портів (АМПУ) та Адміністрації річкових портів України тощо. Все це обумовлює актуальність та значущість обраної тематики. 
Аналіз останніх досліджень, у яких започатковано вирішення проблеми. Дослідженню розвитку водного транспорту присвячено праці вітчизняних та закордонних вчених. Питання законодавчого та нормативно-правового регулювання розвитку транспортної системи України у своїх працях розглядають Метеленко Н. Г та Шмиголь Н. М. [5], що дозволило їм обгрунтувати пріоритетні напрями підвищення якості розвитку транспортної системи в контексті євроінтеграції; систематизації нормативно-правового забезпечення змішаних перевезень на національному та міжнародному рівнях проведено у [6]. Дослідженню ролі водних ресурсів у розвитку транспортного комплексу країни присвячені праці Касич А. О. [7]. Аналізу проблем морського комплексу України та формулювання національних морських інтересів в сучасних геополітичних та економічних умовах в Чорноморському регіоні присвячено праці Буркинського Б. В. та Степанової К. В. [8]. Питання щодо стану та принципів формування державного управління національними ринками транспортних послуг розглядаються Ільченко С. В. [9]. Маслій Н. Д. висвітлено актуальні проблеми розвитку внутрішнього водного транспорту [10].

Серед вітчизняних вчених, що досліджують питання конкурентних переваг та конкурентоспроможності водного транспорту слід відмітити доробки Дубовик Н. В. [11], якою обгрунтовано можливості застосування існуючих підходів до оцінки конкурентоспроможності при оцінці конкурентоспроможності підприємств сервісної діяльності на морському транспорті. Аналіз транзитних перевезень вантажів через морські торговельні порти проведено Карпенко О. О. та Продченко Г. Ю. [12], за результатами якого визначено фактори, що призвели до скорочення їх обсягів та запропоновано заходи щодо їх збільшення. В роботі Кібік О. М. та Жихарєвої В. В. [13] досліджено процес формування конкурентних переваг підприємств морського транспорту України, що дозволило визначити особливості формування конкурентного середовища підприємств портової діяльності і судноплавних компаній та виявити чинники, які обумовлюють рівень конкурентоспроможності підприємств морського транспорту. Колективом авторів у роботі [14] охарактеризовано конкурентну позицію морських торговельних портів України у чорноморському регіоні, що дозволило виявити та дослідити актуальні проблеми формування конкурентної політики портів та визначити заходи, які сприятимуть покращенню конкурентної позиції за рахунок переходу на інноваційний шлях розвитку. Чередниченко В. В. [15] на основі аналізу стану розвитку морських портів України встановлено проблеми їхнього функціонування та державного регулювання їхньою інфраструктурою, що слугувало базисом до дослідження чинників, які впливають на конкурентоспроможність розвитку морських портів, та розроблення пропозицій щодо ії підвищення.

Проведений аналіз наукової літератури свідчить про достатнє теоретичне обгрунтування питань нормативно-правового, економічного, технологічноінформаційного забезпечення водного транспорту України, проте питання реалізації суб'єктами ринку транспортних послуг конкурентних переваг у сучасних умовах розвитку трансконтинентальних маршрутів залишаються актуальними та потребують додаткових досліджень.

Цілі статті. Метою роботи є визначення передумов реалізації конкурентних переваг водного транспорту України.

Виклад основного матеріалу дослідження 3 повним обгрунтуванням отриманих наукових результатів. На даний час більшість вантажних перевезень шляхами України здійснюється автомобільним транспортом, як і у 80 -х роках минулого століття, проте їхні обсяги скоротилися із 93,49\% у 1980 році до 72,65\% у 2019 році. Водним транспортом перевозиться вантажів щороку все менше, про що свідчать статистичні дані (табл. 1) і у 2019 році становлять лише $0,13 \%$ та $0,25 \%$ від загального 
обсягу перевезення вантажів всіма видами транспорту морським та річковим видами транспорту відповідно.

Таблиця 1

Обсяги вантажних перевезень водним транспортом України

\begin{tabular}{|c|c|c|c|c|c|c|c|c|c|}
\hline \multirow{2}{*}{$\begin{array}{c}\text { Перевезення вантажів за } \\
\text { видами водного } \\
\text { транспорту, тис. тонн }\end{array}$} & \multicolumn{9}{|c|}{ Роки } \\
\hline & 1980 & 1990 & 2000 & 2010 & 2016 & 2017 & 2018 & 2019 & 2020 \\
\hline Морський & 47061,0 & 53253,3 & 6316,3 & 4067,8 & 3032,5 & 2253,1 & 1892 & 2120,3 & 1943,2 \\
\hline $\begin{array}{c}\text { у \% від загального обсягу } \\
\text { перевезення вантажів } \\
\text { всіма видами транспорту }\end{array}$ & 1,00 & 1,00 & 0,41 & 0,23 & 0,20 & 0,14 & 0,12 & 0,13 & 0,32 \\
\hline Річковий & 51340,6 & 65728,1 & 8349,8 & 6989,5 & 3641,8 & 3640,2 & 3698 & 3990,2 & 3656,8 \\
\hline $\begin{array}{c}\text { у \% від загального обсягу } \\
\text { перевезення вантажів } \\
\text { всіма видами транспорту }\end{array}$ & 1,09 & 1,24 & 0,55 & 0,40 & 0,24 & 0,23 & 0,23 & 0,25 & 0,61 \\
\hline
\end{tabular}

Джерело: складено та розраховано автором на основі даних [16].

Проте у 2020 році відбувся суттєвий перерозподіл структури перевезень всіма видами транспорту (табл. 2), що обумовлено обмеженнями руху як територією окремої країни, так і між державами через пандемією загальносвітового масштабу Covid-19. Такі події призвели до вкрай негативних явищ у сфері транспорту. По-перше, загальний обсяг перевезення вантажів всіма видами транспорту у 2020 році становить лише $38 \%$ порівняно з 2019 роком. По-друге, у шість разів скоротилися перевезення вантажів автомобільним транспортом та становлять лише 31,89\% у структурі перевезень (у 2019 році $-72,65 \%)$. По-третє, обсяги вантажів, які перевозилися залізничними шляхами, майже не скоротилися (2019 рік - 312,9 млн. тонн, тобто зменшення на 2,4\%), проте у структурі вантажів перевищують 50\%. По-четверте, обсяги перевезень вантажів трубопроводом також дещо зменшились (на 13,45\%), проте їх частка у структурі зросла до 16,25\%. Щодо обсягів перевезень вантажів водним транспортом, то вони також зазнали скорочення на $0,08 \%$ та не зважаючи на те, що їхня частка у структурі в порівнянні з попередніми роками зросла у два рази, зазначений вид транспорту є нажаль найменш використовуваним.

Таблиця 2

Перевезення вантажів за видами транспорту України у 2020 році

\begin{tabular}{|l|c|c|c|c|c|c|}
\hline \multirow{2}{*}{ Обсяг перевезень } & \multicolumn{5}{|c|}{ Вид транспорту } \\
\cline { 2 - 8 } & $\begin{array}{c}\text { заліз- } \\
\text { ничний }\end{array}$ & $\begin{array}{c}\text { морсь- } \\
\text { кий }\end{array}$ & $\begin{array}{c}\text { річко- } \\
\text { вий }\end{array}$ & $\begin{array}{c}\text { автомо- } \\
\text { більний }\end{array}$ & $\begin{array}{c}\text { авіа- } \\
\text { ційнийн }\end{array}$ & $\begin{array}{c}\text { трубо- } \\
\text { провідний }\end{array}$ \\
\hline млн. тонн & 305,5 & 1,9 & 3,7 & 191,4 & 0,1 & 97,5 \\
\hline $\begin{array}{l}\text { у \% від загального обсягу перевезення } \\
\text { вантажів всіма видами транспорту }\end{array}$ & 50,91 & 0,32 & 0,61 & 31,89 & 0,02 & 16,25 \\
\hline
\end{tabular}

Джерело: складено та розраховано автором на основі даних [16].

Слід зазначити, що перевезення вантажів як внутрішнім водним (річковим), так і морським видами транспорту є одним із найбільш дешевих (найнижча собівартість у перерахунку на одну умовну тону вантажу) та екологічних видів вантажоперевезень (порівняно низькі капітальні інвестиції, необхідні для відновлення галузі та екології). Проте маючи розгалужене річкове покриття та вихід к морю, інфраструктура водного транспорту України нажаль $\epsilon$ нерозвиненою та знаходиться у занепаді через довготривалу відсутність стимулювання розвитку. Така бездіяльність у деяких випадках та недоцільна політика розвитку (зокрема обтяжливість податкового навантаження водного транспорту та неврегульованість тарифів, непроведення днопоглиблювання 
експлуатаційних ділянок річок та деяких територій поблизу морських портів тощо) як 3 боку державних органів влади, відповідальних інституцій, так і з боку державних підприємств та підприємств приватного сектору, призвели до обміління річок та викликали неможливість повного навантаження суден не тільки через велику зношеність суден, а й необхідністю навантаження вантажу меншої ваги, через те здійснення перевезень із меншою швидкістю тощо. Все це сприяло розвитку інших видів транспортування вантажів та іншими шляхами.

Враховуючи євроінтеграційну та світову направленість економіки України розвиток водного транспорту України $є$ вкрай важливою та нагальною проблемою, що потребує особливої уваги та обгрунтованих рішень. Однією із складових водного транспорту є внутрішній водний транспорт. 3 01.01.2022 року набере чинності Закон України «Про внутрішній водний транспорт» [4], дію якого націлено на створення сприятливих умов для розвитку водного транспорту України з метою задоволення у доступних, якісних та безпечних перевезеннях, а також регламентує певні норми функціонування внутрішнього водного транспорту. 3 метою визначення можливих конкурентних переваг цього транспорту на світовій арені, доцільно провести порівняння їхньої діяльності за основними аспектами.

На підставі статистичних даних [16] визначено, що в Україні внутрішніми водними шляхами транспортуються переважно будівельні види вантажів $(46,7 \%)$, різна руда $(16,1 \%)$, хлібні види вантажів $(11,3 \%)$ та різні метали $(10,2 \%)$. За видами сполучення переважають каботажні перевезення (64,4\%), під якими розуміється, згідно зі статтею 97 Митного кодексу України [17], перевезення українських та іноземних товарів шляхом завантаження їх на морське (річкове) судно в одному пункті на митній території України i транспортування в інший пункт території України, де здійснюватиметься їх вивантаження. При цьому на кінець 2017 року за типом третину від загальної кількості складають суховантажні судна (455 од.) та майже третину службово-допоміжні (416 од.), а згідно з даними Державної служби морського та річкового транспорту України [18] на кінець 2019 року в Державному судновому реєстрі України зареєстровано 1284 річкових суден, 184 судна - змішаного району плавання та інші.

В останні роки на фоні інтеграційних процесів України та ії представлення на транс'європейських шляхах, проводяться роботи з удосконалення не тільки нормативноправового регулювання, перегляду відповідної державної та регіональної політики, а й технічного розвитку. Зокрема протягом 2020 року проведені роботи з днопоглиблювання загальним обсягом 4957,6 тис. м $^{3}$, серед у тому числі експлуатаційного характеру за рахунок власного флоту ДП «АМПУ» - 2686,7 тис. ${ }^{3}$ [19] та передано на аутсорсинг 420 тис. м $^{3}$ капітального днопоглиблювання. Поміж цього частина експлуатаційні дноочисні роботи були проведено і на річкових внутрішніх водних шляхах загального користування: р. Прип'ять (130 тис. м $\left.^{3}\right)$ та р. Дніпро (352,7 тис. м $\left.^{3}\right)$.

Зіставляючи стан розвитку водного транспорту України 3 країнами Європейського союзу слід зазначити, що Україна посідає п'яте місце серед європейських країн, поступаючись Фінляндії, Німеччині, Франції та Польщі (табл. 3), за протяжністю внутрішніх водних шляхів, загальна довжина яких складає 2729,3 км, 3 яких майже половина (1 292,3 км або 47,35\%) включено до Європейської угоди про найважливіші внутрішні водні шляхи міжнародного значення. В процесі дослідження визначено, що найбільша ефективність перевезень вантажів внутрішнім водним транспортом спостерігається в Нідерландах та Німеччині, враховуючи обсяги перевезень вантажів та довжину внутрішніх водних шляхів. Слід зазначити, що трьома основними ріками, які використовують у перевезенні вантажів $є$ Рейн, Майн та Дунай, якими перевозяться нафта, вугілля, метали, добрива, лісоматеріали, зерно, сільськогосподарська продукція тощо. 
Таблиця 3

Довжина внутрішніх водних шляхів України та країн Свропи і обсяги перевезеннями ними вантажів станом на кінець 2019 року

\begin{tabular}{|c|c|c|c|c|c|c|c|c|c|c|c|c|c|c|c|c|c|c|c|}
\hline Країна & 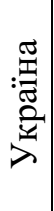 & . & 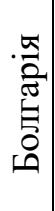 & $\frac{\sqrt[a]{x}}{x_{0}}$ & 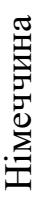 & 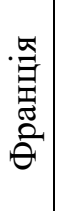 & 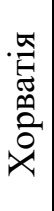 & 氬 & 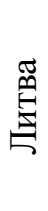 & 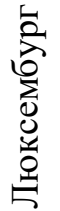 & 胥 & 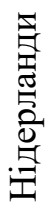 & $\begin{array}{l}\cdot \frac{\pi}{2} \\
\stackrel{0}{0} \\
\frac{0}{4}\end{array}$ & 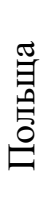 & 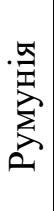 & 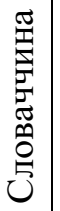 & 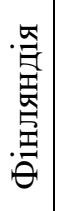 & $\begin{array}{l}\text { 可 } \\
\text { 总 } \\
\text { 当 }\end{array}$ & 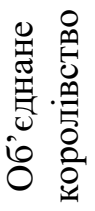 \\
\hline Довжина, км & $\begin{array}{c}\text { กิ } \\
\text { N }\end{array}$ & I & $\begin{array}{l}\stackrel{0}{\ominus} \\
\frac{\sigma}{+}\end{array}$ & 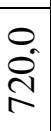 & $\begin{array}{l}0 \\
6 \\
6 \\
1\end{array}$ & $\begin{array}{l}0 \\
\hat{N} \\
\infty \\
\forall\end{array}$ & $\begin{array}{l}a \\
\hat{0} \\
0 \\
-\end{array}$ & $\begin{array}{l}0 \\
\text { กิ } \\
\text { n } \\
-\end{array}$ & $\begin{array}{l}\circ \\
\text { ஜ̊ } \\
\qquad\end{array}$ & 1 & 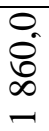 & I & $\frac{0}{n}$ & Ñ & 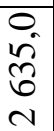 & $\begin{array}{l}0 \\
\text { N } \\
\text { I }\end{array}$ & $\begin{array}{l}0 \\
\stackrel{1}{1} \\
\infty\end{array}$ & 1 & 1 \\
\hline $\begin{array}{c}\text { Перевезення } \\
\text { вантажів, тис. } \\
\text { тонн }\end{array}$ & $\begin{array}{l}\infty \\
6 \\
\curvearrowleft \\
\infty\end{array}$ & $\begin{array}{l}0 \\
2 \\
\delta \\
n \\
n\end{array}$ & $\begin{array}{l}0 \\
0 \\
\dot{y} \\
\infty\end{array}$ & $\begin{array}{l}0 \\
\frac{0}{2}\end{array}$ & $\begin{array}{l}0 \\
\emptyset \\
\varnothing \\
0 \\
\delta\end{array}$ & $\begin{array}{l}\frac{0}{m} \\
\frac{m}{b} \\
\dot{b}\end{array}$ & $\begin{array}{l}\frac{0}{\sigma} \\
\frac{\sigma}{b}\end{array}$ & $\begin{array}{l}0 \\
\infty \\
\infty \\
\infty\end{array}$ & $\begin{array}{l}0 \\
\text { N }\end{array}$ & $\begin{array}{l}\stackrel{0}{\tilde{r}} \\
\stackrel{+}{0}\end{array}$ & ई̊ & 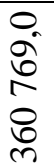 & $\begin{array}{l}0 \\
i \\
\infty\end{array}$ & $\begin{array}{l}\stackrel{0}{2} \\
\infty \\
N\end{array}$ & $\begin{array}{l}\text { कृ } \\
\text { dे } \\
m \\
m\end{array}$ & 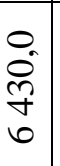 & $\begin{array}{l}0 \\
\hat{n} \\
\text { N }\end{array}$ & $\begin{array}{l}0 \\
\frac{0}{6}\end{array}$ & \begin{tabular}{l}
0 \\
0 \\
\multirow{8}{*}{} \\
0
\end{tabular} \\
\hline
\end{tabular}

Джерело: складено автором на основі даних [20-21].

В деяких країнах спостерігається виразна взаємозалежність між обсягами перевезення вантажів та промисловістю, яка формує переважну вантажну базу. Так, Нідерланди, Німеччина і Бельгія у сукупності формують більше $80 \%$ обсягів перевезень у загальній кількості по Європі. При цьому флотом Нідерланди на ріках експлуатується майже 4,8 тис. суден (більше $65 \%$ від загальної кількості суден по Європі), а німецьким флотом - майже 1,2 тис. суден (більше 15\%). Зауважимо, що внутрішні водні шляхи Європи типізовані і використовуються уніфіковані баржі, вантажопідйомність яких залежить від глибини. Все це свідчить про високу розвиненість та масштабе використання потенціалу внутрішніх водних шляхів Свропи із урахуванням високих показників екологічної стійкості та енергоефективності, підтримуючи безпеку клімату та навколишнього середовища.

Другою важливою складовою водного транспорту є морський. Наразі в Україні представлено 13 морських портів, зокрема Білгород - Дністровський, Бердянськ, Ізмаїл, Чорноморськ, Маріуполь, Миколаїв, Одеса, Ольвія, Рені, Скадовськ, «Усть-Дунайськ», Херсон, Південний, загальною пропускною спроможністю 52600 тис. тонн на рік $з$ обробки наливних вантажів, 191160,5 тис. тонн на рік - сухих вантажів, 2961,3 тис. ТЕУ - контейнерних вантажів (табл. 4). Враховуючи вантажопотік і пропускну спроможність морських портів, їхня завантаженість досить незначна. Середня завантаженість морських портів України нажаль знаходиться нижче 50\%.

При цьому слід зазначити, що більша частина вантажів перевозиться за закордонним сполученням $(51,4 \%)$, а за видом вантажу переважно транспортуються різні метали (48,6\%) та хлібні вироби (27,7\%) [16]. Відмітимо, що відповідно до [18] в Україні зареєстровано 694 морських суден, проте за даними 2017 року загальна кількість морських суден становила 3334 од., у тому числі і пасажирські, серед яких за типом, як і поміж серед річкових, переважають суховантажні, складаючи 1280 од. $(38,4 \%)$, спеціального призначення (847 од. або 25,4\%) та службово-допоміжні (608 од. або $18,2 \%)$. Основною проблемою, що обумовлює низьку завантаженість морських портів України, $\epsilon$ невідповідність технічних характеристик акваторій портів сучасним використовуваним видам суден, що можуть заходити до морського порту. Проте у 2020 році проведено днопоглиблення на акваторії морських портів загальним обсягом 4054,9 тис. м³ 3 яких експлуатаційного характеру, здійснених ДП «АМПУ», 1415,3 тис. $\mathrm{m}^{3}$ на акваторії порту Бердянськ, 1090,0 тис. м $^{3}$ - Маріуполь, 67,8 тис. м $^{3}$ - Одеса, 683,8 тис. м $^{3}$ на Херсонському морському та Бузько-Дніпровсько-лиманському каналах, 
503,2 тис. м³ на таких підхідних каналах як Дністровсько-лиманський та Дністровсько-

Таблиця 4

Пропускна спроможність, вантажопотік та завантаженість морських портів

\begin{tabular}{|c|c|c|c|c|c|c|c|c|c|}
\hline \multirow{3}{*}{ Морські порти } & \multicolumn{3}{|c|}{$\begin{array}{c}\text { Пропускна спроможність порту } \\
\text { з обробки } \\
\end{array}$} & \multicolumn{3}{|c|}{$\begin{array}{l}\text { Вантажопотік, } \\
\text { тис. тонн }\end{array}$} & \multirow{2}{*}{\multicolumn{3}{|c|}{$\begin{array}{c}\text { Рівень } \\
\text { завантаженості } \\
\text { порту, \% }\end{array}$}} \\
\hline & \multirow{2}{*}{$\begin{array}{c}\text { наливних } \\
\text { вантажів, } \\
\text { тис. тонн / } \\
\text { рік }\end{array}$} & \multirow{2}{*}{$\begin{array}{c}\text { сухих } \\
\text { вантажів, } \\
\text { тис. тонн } \\
\text { / рік }\end{array}$} & \multirow{2}{*}{$\begin{array}{c}\text { контей- } \\
\text { нерів, } \\
\text { тис. ТЕУ } \\
\text { / рік }\end{array}$} & \multirow[b]{2}{*}{2017} & \multirow[b]{2}{*}{2018} & \multirow[b]{2}{*}{2019} & & & \\
\hline & & & & & & & 2017 & 2018 & 2019 \\
\hline $\begin{array}{l}\text { Білгород- } \\
\text { Дністровський }\end{array}$ & - & 1710,0 & - & 353 & 235 & 117 & 20,6 & 13,7 & 6,8 \\
\hline Бердянськ & 600,0 & 5600,0 & - & 2398 & 1813 & 2074 & 38,7 & 29,2 & 33,5 \\
\hline Ізмаїл & 70,0 & 9220,0 & 44,5 & 5098 & 4683 & 4283 & 46,3 & 42,6 & 38,9 \\
\hline Чорноморськ & 6600,0 & 47245,0 & 1150,0 & 21088 & 21535 & 26153 & 21,5 & 21,9 & 26,6 \\
\hline Маріуполь & - & 18310,0 & 50,0 & 6516 & 5874 & 6483 & 32,2 & 29,0 & 32,0 \\
\hline Миколаїв & 4900,0 & 26176,0 & 20,0 & 23535 & 29205 & 33433 & 73,9 & 91,7 & 105,0 \\
\hline Одеса & 26580,0 & 21044,0 & 930,0 & 24136 & 21698 & 25344 & 28,9 & 26,0 & 30,4 \\
\hline Ольвія & - & 5000,0 & - & 2510 & 2246 & 3097 & 50,2 & 44,9 & 61,9 \\
\hline Рені & 2000,0 & 6000,0 & 4,0 & 1125 & 1333 & 1275 & 13,8 & 16,3 & 15,6 \\
\hline Скадовськ & - & 1320,0 & - & 21 & 8 & 5 & 1,6 & 0,6 & 0,4 \\
\hline «Усть-Дунайськ» & - & 250,0 & - & 54 & 51 & 71 & 21,6 & 20,4 & 28,4 \\
\hline Херсон & 550,0 & 7385,5 & 12,8 & 3341 & 3075 & 3803 & 39,6 & 36,5 & 45,1 \\
\hline Південний & 11300,0 & 41900,0 & 750,0 & 41898 & 42702 & 53863 & 51,0 & 52,0 & 65,6 \\
\hline Всього & 52600 & 191160,5 & 2961,3 & 132578 & 135171 & 160001 & 37,0 & 37,8 & 44,7 \\
\hline
\end{tabular}

Цареградського гирла, а також 294,8 тис. м³ - морського підхідного каналу глибоководного суднового ходу Дунай - Чорне море. Капітальне днопоглиблення, зокрема реконструкція операційної акваторії 1-го ковша Сухого лиману морського порту Чорноморськ, обсягом у 2270,9 тис. м ${ }^{3}$ здійснено на аутсорсингу.

Досліджуючи Україну в розрізі загальної ваги товарів, що обробляються у всіх морських портах країн Європи, підкреслимо значний вантажопотік від загальних обсягів таких країн як Нідерланди $(12,73 \%)$, Італія (10,65\%), Іспанія $(10,41 \%)$, Об'єднане Королівство (10,19\%), Туреччина (10,02\%).

Останні п'ять років рушійною силою розвитку портової інфраструктури залишається зростаючий вантажопотік на шляху між Європою та Азією за транскаспійським міжнародним транспортним маршрутом, проміжним пунктом якого можуть слугувати морські порти України. Проте для ефективного їх впровадження як інтеграційної крапки необхідним $є$ формування єдиного цифрового інформаційного простору на різних інтеграційних крапках маршруту та цифрового транспортного коридору, реалізація яких можлива за допомогою використання штучного інтелекту і використання технологій Blockchain, що забезпечують прозорість, безпеку, швидкість, відсутність централізованого посередника, автоматизацію та контроль.

Висновки. Таким чином, для зменшення існуючих диспропорцій обсягів перевезень різними видами транспорту, на думку автора, необхідним є проведення детального аналізу наявних проблем, що потребують нагального вирішення, та конкурентних переваг водного транспорту України із подальшим їхнім оцінюванням та розробленням прикладних інструментів реалізації. Враховуючи зазначену проблематику функціонування водного транспорту України та зважаючи на світові тенденції розвитку транспортної системи доцільним $\epsilon$ вирішення проблем нормативно-правового регулювання, а також економіко-екологічного та технологічно-інформаційного 
характеру. Зокрема підвищення конкурентоспроможності водного транспорту шляхом:

Таблиця 5

Загальна вага товарів, що обробляються у всіх морських портах країн Європи, тис. тонн

\begin{tabular}{|l|c|c|c|c|c|}
\hline \multirow{2}{*}{ Країна } & \multicolumn{5}{|c|}{ Роки } \\
\cline { 2 - 6 } & 2015 & 2016 & 2017 & 2018 & 2019 \\
\hline Нідерланди & 594272 & 588772 & 595810 & 604542 & 607527 \\
\hline Італія & 458020 & 461990 & 475164 & 501958 & 508074 \\
\hline Іспанія & 447048 & 451255 & 485805 & 497812 & 496912 \\
\hline Об'єднане Королівство & 496708 & 484048 & 481815 & 483305 & 486094 \\
\hline Туреччина & 411783 & 425853 & 465981 & 454370 & 478116 \\
\hline Франція & 297880 & 292160 & 302840 & 308629 & 302288 \\
\hline Німеччина & 295918 & 297137 & 299189 & 296181 & 294533 \\
\hline Бельгія & 241459 & 253543 & 257865 & 270317 & 277783 \\
\hline Норвегія & 193605 & 200143 & 210649 & 215438 & 211207 \\
\hline Греція & 167036 & 175100 & 181261 & 190523 & 194468 \\
\hline Швеція & 169685 & 171324 & 175964 & 179949 & 170557 \\
\hline Фінляндія & 99962 & 105887 & 110468 & 116764 & 120488 \\
\hline Польща & 69530 & 72926 & 78076 & 91798 & 93864 \\
\hline Данія & 95098 & 95829 & 94638 & 95989 & 93727 \\
\hline Португалія & 86769 & 91344 & 93356 & 90361 & 85320 \\
\hline Латвія & 67811 & 60962 & 58687 & 62660 & 59046 \\
\hline Ірландія & 50666 & 50758 & 53351 & 55120 & 53251 \\
\hline Румунія & 44533 & 46295 & 46182 & 49107 & 53101 \\
\hline Литва & 43128 & 46236 & 49856 & 52462 & 52244 \\
\hline Естонія & 34965 & 33596 & 34801 & 35947 & 37760 \\
\hline Болгарія & 27166 & 28685 & 30953 & 27868 & 30997 \\
\hline Словенія & 19931 & 21171 & 22311 & 23127 & 22114 \\
\hline Хорватія & 18930 & 18551 & 20798 & 21573 & 20580 \\
\hline Ісландія & 7137 & 7446 & 7672 & 7263 & 7662 \\
\hline Кіпр & 10268 & 10259 & 7860 & 6948 & 7428 \\
\hline Мальта & 3705 & 3788 & 4114 & 4559 & 5195 \\
\hline Чорногорія & 1487 & 1617 & 2096 & 1956 & 2035 \\
\hline
\end{tabular}

Джерело: складено автором на основі даних [21].

розвитку інфраструктури водного транспорту (наземної, причальної, водних шляхів), синхромодальних перевезень, круїзного туризму у мовах пандемії, геоінформаційної інфраструктури водного транспорту на засадах хмарних технологій, нейронних мереж тощо; застосування платформ e-supply chain management та цифрового бренд-менеджменту як імперативу професійної діяльності; проведення заходів 3 екологізації флоту та відтворення природних ресурсів морів і річок; технічного та технологічного оновлення суб'єктів водного транспорту, проведення страхування майна та відповідальності судновласників і портів; масштабного впровадження та використання ІоТ на підприємствах водного транспорту, e-contracting, e-invoicing, e-docflow на засадах eIDAS тощо. Реалізація зазначених заходів сприятиме впровадженню в Україні концепції «розумного порту» («смарт порту»), яка є головним трендом в трансформації та цифровізації портів світу та передбачає об'єднання всіх учасників глобального ланцюга поставок у єдину взаємопов'язану мережу на основі цифрової платформи із тестуванням штучного інтелекту. Саме цифровізація є однією із значних пріоритетних змін в транспортній системі, що дозволить миттєво обмінюватись даними бізнес-аналітикою в режимі реального часу, спільно вирішувати бізнес-задачі та приймати дієві рішення, тобто сприятиме ефективній координації та співробітництву між учасниками при формуванні чітких ланцюгів поставок. 
Для учасників такого процесу, зокрема морських та річкових портів i ïx суб'єктів підприємництва, успішне впровадження системи портової спільноти дозволить не тільки підвищити рівень автоматизації операцій, стандартизувати обмін інформації із одночасним забезпеченням конфіденційності i безпеки приватних даних компаній, митниць, адміністрацій (у тому числі впровадити ІТ-системи єдиного інтерфейсу), що допоможе якісному збору даних без втрат та іiі спотворення, а у підсумку збільшити ефективність використання інфраструктури та ресурсів терміналів, скоротити час проходження вантажів через порти, наростити продуктивність терміналів в акваторії порту, прискорити процедури декларування та отримання торгових дозволів, скоротити помилки в оформленні перевізних документів, оптимізувати трафік транспорту на прилеглих територіях, підвищити безпеку руху суден в акваторії портів, підвищити ефективність комунікацій між учасниками ланцюгів поставок тощо.

\section{Список бібліографічного опису:}

1.Про Цілі сталого розвитку України на період до 2030 року : Указ Президента України від 30.09.2019 № 722/2019. Дата оновлення: 30.09.2019. URL: https://zakon.rada.gov.ua/laws/show/722/2019\#Text (дата звернення: 26.02.2021).

2.Про схвалення Національної транспортної стратегії України на період до 2030 року: Розпорядження Кабінету Міністрів України від 30.05.2018 № 430-р. Дата оновлення: 30.05.2018. URL: https://zakon.rada.gov.ua/laws/show/4302018-\%D1\%80\#Text (дата звернення: 26.02.2021).

3.Про затвердження Стратегії розвитку морських портів України на період до 2038 року Розпорядження Кабінету Міністрів України від 11.07.2013 № 548-р. Дата оновлення: 23.12.2021. URL: https://zakon.rada.gov.ua/laws/show/5482013-\%D1\%80\#Tеxt (дата звернення: 26.02.2021).

4.Про внутрішній водний транспорт: Закон України від 03.12.2020 № 1054-IX. Дата оновлення: 03.12.2020. URL: https://zakon.rada.gov.ua/laws/show/ 1054-20\#Техt (дата звернення 26.02.2021).

5.Метеленко Н.Г., Шмиголь Н. М. Законодавче регулювання та управління якістю транспортної системи України. Приазовський економічний вісник. Запоріжжя, 2018 Вип. 3(08). С. 25-29. URL: http://pev.kpu.zp.ua/journals/2018/3_08_uk/7.pdf (дата звернення: 26.02.2021).

6.Маслій Н. Д. Імплементація нормативно-правового забезпечення змішаних перевезень на національному та міжнародному рівнях. Причорноморські економічні студіï. Одеса, 2020. Вип. 51. С. 52-55. DOI: https://doi. org/10. 32843/bses. 51-8.

7.Касич А. О. Водні ресурси України як основа забезпечення стійкого розвитку транспортного комплексу. Ефективна економіка. Київ, 2018. №8. URL: http://www.economy.nayka.com.ua/pdf/8_2018/9.pdf (дата звернення: 26.02.2021).

8.Burkinskyi B., Stepanova K. National Maritime Interests of Ukraine in the Black Sea-Azov Basin. Economics. Ecology. Socium. Odessa, 2017. Is. 1 (1). P. 12-23. URL: http://ees-journal.com/index.php/journal/article/view/37/12 (дата звернення: 26.02.2021). 9. Ilchenko S. V. Public management of national markets of transport services: status and principles of formation. Science and education : trends and prospects. New York: Ascona Publishing, United States of America, 2018. P. 38-47. URL: http://conferencii.com/files/archive/2018-02.pdf (дата звернення: 26.02.2021).

10. Maslii N., Mamunenko M. Current problems of the development of inland water transport of Ukraine. Economic and business administration development:scientific currencies and solutions: Abstracts I International scientific-practical conference, Kiev, 22 October 2020. Kiev: NAU, 2020. P. 283-285.

11. Дубовик Н. В. Оцінка конкурентоспроможності підприємств сервісної діяльності на морському транспорті. Розвиток методів управління та господарювання на транспорті. Одесса, 2012. № 4 (41). С. 166-185.

12. Карпенко О. О., Продченко Г. Ю. Аналіз транзитних перевезень вантажів через морські торговельні порти України. Водний транспорт. Київ, 2012. Вип. 3. С. 123-128.

13. Кібік О. М., Жихарєва В. В. Формування конкурентних переваг підприємств морського транспорту України. Економічні інновачії. Одеса, 2011. Вип. 45. С. 97-103.

14. Рощіна Н. В., Ширяєва Л. В., Афанасьєва О. К. Актуальні проблеми формування конкурентної політики морських торговельних портів України. Вісник Національного університету «Львівська політехніка»: Менеджмент та підприємниитво в Україні: етапи становлення. Львів, 2009. Вип. 657. С. 443-449.

15. Чередниченко В. В. Основні чинники конкурентоспроможності українських портів в умовах глобалізації. Ефективна економіка. Київ, 2013. № 10. URL: http://www.economy.nayka.com.ua/?op=1\&z=2427 (дата звернення: 26.02.2021).

16. Державна служба статистики України. Статистична інформація. Tранспорт. URL: http://www.ukrstat.gov.ua/operativ/menu/menu_u/tr.htm (дата звернення: 26.02.2021).

17. Митний кодекс України: Закон України від 13.03.2012 р. № 4495-VI. Дата оновлення: 01.01.2021. URL: https://zakon.rada.gov.ua/laws/show/4495-17\#Техt (дата звернення: 26.02.2021).

18. Державна служба морського та річкового транспорту України. Державний судновий реєстр України. URL: https://marad.gov.ua/ua/poslugi/derzhavnij-sudnovij-reyestr-ukrayini (дата звернення: 26.02.2021).

19. Адміністрація морських портів України. Презентаційні матеріали. URL: http://www.uspa.gov.ua/propidpriemstvo/firmova-grafika-ta-reklamni-materiali-prezentatsiji (дата звернення: 26.02.2021).

20. Перелік внутрішніх водних шляхів, що належать до категорії судноплавних: постанова Кабінету Міністрів України від 12 червня 1996 р. № 640. URL: https://zakon.rada.gov.ua/laws/show/640-96-\%D0\%BF\#Техt (дата звернення: 26.02.2021).

21. Eurostat. Transport - Overview. URL: https://ec.europa.eu/eurostat/web/ transport/overview (дата звернення: 
26.02.2021).

22. Адміністрація морських портів України. Реєстр морських портів. URL: http://www.uspa.gov.ua/reestr-morskikhportiv (дата звернення: 26.02.2021).

\section{References:}

1.On the Goals of Sustainable Development of Ukraine until 2030: Decree of the President of Ukraine from 30.09.2019 No 722/2019. Available at: https://zakon.rada.gov.ua/laws/show/722/2019\#Text (accessed 26.02.2021) [in Ukrainian]

2.On approval of the National Transport Strategy of Ukraine for the period up to 2030: Order of the Cabinet of Ministers of Ukraine from 30.05.2018 No 430-p. Available at: https://zakon.rada.gov.ua/laws/show/430-2018-\%D1\%80\#Text (accessed 26.02.2021) [in Ukrainian]

3.On approval of the Strategy for the development of seaports of Ukraine for the period up to 2038 Order of the Cabinet of Ministers of Ukraine from 11.07.2013 No 548-p. Available at: https://zakon.rada.gov.ua/laws/show/548-2013-\%D1\%80\#Text (accessed 26.02.2021) [in Ukrainian]

4.On inland water transport: Law of Ukraine from 03.12.2020 No 1054-IX. Available at: https://zakon.rada.gov.ua/laws/show/ 1054-20\#Text (дата звернення 26.02.2021) [in Ukrainian]

5.Metelenko N.H., Shmyhol N.M. Legislative regulation and management of quality of the transport system of Ukraine. Pryazovskyi economic herald, 2018, vol. 3(08), pp. 25-29. Available at: http://pev.kpu.zp.ua/journals/2018/3_08_uk/7.pdf (accessed 26.02.2021) [in Ukrainian]

6.Maslii N. Implementation of regulatory and legal support for multimodal transportation at the national and international levels. Black sea economic studies, 2020, vol. 51, pp. 52-55. doi: https://doi. org/10. 32843/bses. 51-8. [in Ukrainian]

7.Kasych A. O. Water resources of ukraine as a basis for ensuring sustainable development of the transport complex. Efektyvna ekonomika, 2018, No 8. Available at: http://www.economy.nayka.com.ua/pdf/8_2018/9.pdf (accessed 26.02.2021) [in Ukrainian]

8.Burkinskyi B., Stepanova K. National Maritime Interests of Ukraine in the Black Sea-Azov Basin. Economics. Ecology. Socium, 2017, vol. 1 (1), pp. 12-23. Available at: http://ees-journal.com/index.php/journal/article/view/37/12 (accessed 26.02.2021).

9.Ilchenko S. V. Public management of national markets of transport services: status and principles of formation. Science and education : trends and prospects, 2018, pp. 38-47 Available at: http://conferencii.com/files/archive/2018-02.pdf (accessed 26.02.2021).

10. Maslii N., Mamunenko M. Current problems of the development of inland water transport of Ukraine. Abstracts I International scientific-practical conference "Economic and business administration development:scientific currencies and solutions". Kiev, 2020, pp. 283-285.

11. Dubovik N. V. Assessment of the competitiveness of service enterprises in maritime transport. Development of methods of management of transport, 2012, No 4 (41), pp. 166-185 [in Ukrainian]

12. Karpenko O. O., Prodchenko H. Iu. (2012). Analysis of transit transportation of goods through the sea merchant ports of Ukraine. Water transport, 2012, vol. 3, pp. 123-128 [in Ukrainian]

13. Kibik O.M., Zhihareva V.V. Formation of competitive advantages of the enterprises of maritime transport in Ukraine. Economic innovation, 2011, vol. 45, pp. 97-103 [in Ukrainian]

14. Roshchina N. V., Shiryaeva L. V., Afanaseva O. K. Actual problems of formation of a competitive policy of Ukraine's sea trade ports. Bulletin of Lviv Polytechnic National University, 2009, vol. 657, pp. $443-449$ [in Ukrainian] 15. Cherednichenko V. V. (2013). The main factors of competitiveness of Ukrainian ports in the context of globalization. Efektivna ekonomika, 2013, No 10. Available at: http://www.economy.nayka.com.ua/?op=1\&z=2427 (accessed 26.02.2021) [in Ukrainian]

16. State Statistics Service of Ukraine. Statistical information. Transport. Available at: http://www.ukrstat.gov.ua/operativ/menu/menu_u/tr.htm (accessed 26.02.2021) [in Ukrainian]

17. Customs Code of Ukraine: Law of Ukraine from 13.03.2012 No 4495-VI. Available at: https://zakon.rada.gov.ua/laws/show/4495-17\#Text (accessed 26.02.2021) [in Ukrainian]

18. State Maritime and River Transport Service of Ukraine. State Ship Register of Ukraine. Available at: https://marad.gov.ua/ua/poslugi/derzhavnij-sudnovij-reyestr-ukrayini (accessed 26.02.2021) [in Ukrainian]

19. Administration of seaports of Ukraine. Presentation materials. Available at: http://www.uspa.gov.ua/propidpriemstvo/firmova-grafika-ta-reklamni-materiali-prezentatsiji (accessed 26.02.2021) [in Ukrainian]

20. List of inland waterways belonging to the category of navigable: Resolution of the Cabinet of Ministers of Ukraine from 12.06.1996 No 640. Available at: https://zakon.rada.gov.ua/laws/show/640-96-\%D0\%BF\#Text (accessed 26.02.2021) [in Ukrainian]

21. Eurostat. Transport - Overview. Available at: https://ec.europa.eu/eurostat/web/ transport/overview (accessed 26.02.2021) 22. Administration of seaports of Ukraine. Register of seaports. Available at: http://www.uspa.gov.ua/reestr-morskikh-portiv (accessed 26.02.2021) [in Ukrainian]

$$
\text { Дата подання публікації 26.02.2021 p }
$$

